UDC 616.5+ 614.8.026: 616.41

DOI: $10.21668 /$ health.risk/2019.2.07.eng

\title{
CLINICAL AND EPIDEMIOLOGICAL CHARACTERISTICS OF MALIGNANT NEOPLASMS IN THE THYROID GLAND IN CHELYABINSK REGION POPULATION OVER 1998-2016
}

\author{
S.A. Shalaginov ${ }^{1}$, L.Yu.Krestinina ${ }^{1}$, A.S. Domozhirova ${ }^{2}$, S.B. Sergiyko ${ }^{3,4}$ \\ ${ }^{1}$ Urals Research Center for Radiation Medicine, 68 A Vorovsky Str., Chelyabinsk, 454076, Russian Federation \\ ${ }^{2}$ Chelyabinsk Regional Clinical Center for Oncology and Nuclear Medicine, 42 Blyuhera Str., Chelyabinsk, \\ 454076, Russian Federation \\ ${ }^{3}$ South-Ural State Medical University of the Ministry of Healthcare of the Russian Federation, 64 Vorovsky Str., \\ Chelyabinsk, 454092, Russian Federation \\ ${ }^{4}$ City Clinical Hospital № 1, 16 Vorovsky Str., Chelyabinsk, 454048, Russian Federation
}

The paper dwells on assessment of dynamics in incidence with malignant neoplasms in the thyroid gland among Chelyabinsk region population over 1998-2016. Dynamics is taken in different age groups; incidence with different malignant neoplasms is characterized among men and women. The authors took data from major medical and diagnostic institutions in Chelyabinsk region where information about patients suffering from malignant neoplasms in the thyroid gland could be accumulated. We detected 4,467 people with the diagnose confirmed with histological (93.2\%) and cytological (6.8\%) research.

We detected that primary incidence with malignant neoplasms in the thyroid gland tended to grow in Chelyabinsk region and it completely corresponded to the dynamics in the Russian Federation as a whole. This growth was mostly due to an increase in primary incidence among people aged 60 and older. Papillary carcinoma is the most widely spread malignant neoplasm with $68.1 \%$ cases in the overall structure of thyroid gland carcinoma in Chelyabinsk region. This malignant neoplasm tended to grow steadily from $64.2 \%$ in the beginning of the observation period to $73.0 \%$ at the end of it. But at the same time follicular carcinoma tended to decrease from $25.5 \%$ to $18.2 \%$ cases; just as an aggregated share of other carcinoma types which were relatively rare. Average age of men at the moment malignant neoplasms in the thyroid gland were

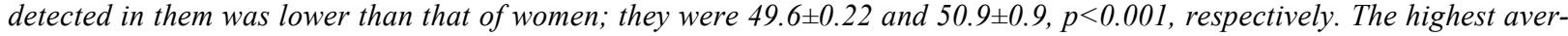
age age was detected for people with non-differentiated malignant neoplasms (66.9 \pm 0.7$)$; the lowest one, for people with follicular carcinoma (49.7 \pm 0.1$), p<0.001$.

Key words: thyroid gland, malignant neoplasm, Chelyabinsk region, population, age, incidence, structure.

A large number of studies performed at different times in different countries, as well as in different regions of Russia were devoted to examining thyroid cancer epidemiology. One would think that all the aspects of thyroid cancer have been covered in these papers. Possible range of incidence rate was estimated as being equal to $0.8-11.2$ per 100,000 persons over the period 1998-2016. The range among males was 0.6-5.0; and among females, 1.2-16.0. The incidence rate among people aged $0-19$ ranged from $0.5--4.2$, and it ranged from 2.1 to 16.8 per 100,000 persons among people older than 60 . However, there are good reasons still attracting epidemiologists' attention to the problem of thyroid cancer. Perhaps, the main one is the increase in the thyroid cancer incidence over the recent years. In Russia, for example, the growth was from 5.8 to 8.3 cases per 100,000 persons [1-6]. Nowadays, it is not clear to what extent this growth is due to improved quality of diagnos-

(C) Shalaginov S.A., Krestinina L.Yu., Domozhirova A.S., Sergiyko S.B., 2019

Sergey A. Shalaginov - Candidate of Medical Sciences, Senior researcher at the epidemiological laboratory (e-mail: Shalaginov@urcrm.ru; tel.: +7 (351) 232-79-14; ORCID: https: //orcid.org/0000-0003-0497-5879).

Lyudmila Yu. Krestinina - Candidate of Medical Sciences, Head of the epidemiological laboratory (e-mail: ludmila@urcrm.ru; tel.: +7 (351) 232-79-18; ORCID: https: //orcid.org/0000-0003-0497-5879).

Alla S. Domozhirova - Doctor of Medical Sciences, Professor, Deputy to Chief Physician responsible for organizational and methodical work (e-mail: 2356563@mail.ru; tel.: +7 (351) 235-65-63; ORCID: https: //orcid.org/0000-0003-0806-3164).

Sergey V. Sergiyko - Doctor of Medical Sciences, Professor, Head of the General and Pediatric Surgery Department (e-mail: ssv_1964@mail.ru; tel.: +7 (351) 728-48-47; ORCID: https: //orcid.org/0000-0001-6694-9030). 
tics, and to what extent due to environmental, medical, and biological or some other factors.

The number of published papers on the problem of thyroid cancer sharply increased after the Chernobyl accident and the catchment area went further beyond the borders of the territory that was actually contaminated with radiation. The problem of thyroid cancer acquired a different meaning for other radioactively-contaminated territories (except the territory around Chernobyl nuclear power station) including the resettlement territory for persons exposed as a result of the Mayak PA activities.

Long time after the onset of radiation contamination in the Urals, the assessment of thyroid cancer risk becomes relevant among the offspring of the exposed population. Up to now, a large number of persons exposed as a result of the Mayak PA activities and their offspring have settled in Chelyabinsk region [7-9]. Taking into account high variability of epidemiological data on thyroid cancer incidence [1-6, 10-19], obtained in different regions, solid substantiation for radiogenic risk assessment requires evaluation of background incidence rate among the population living in Chelyabinsk region.

Iodine deficiency, hypothyroidism associated with it, and a high level of TSH stand out among the main factors contributing to the onset of tumor progression in thyroid gland $[20,21]$. The possibility of tumor development in thyroid gland depends on its functional and morphological status which is gender and age dependent [22]. Malignization risk increases against the background of nodular euthyroid goiter, adenomas and thyroiditis [21, 23].

The thyroid gland is highly radiosensitive and it is especially true for children. A lot of papers have been published so far concerning high risks of malignant neoplasms in the thyroid gland among various groups of irradiated population $^{1}$ [23-25]. When a solid variant of papillary carcinoma develops, it can have a particular importance. Until recently, this variant of papillary carcinoma has been treated as rather rare [27]. However, as it has been shown by recent studies, it amounted to $37 \%$ of papillary carcinomas associated with thyroid gland exposure as a result of Chernobyl accident, and it can now be regarded as radiation-induced thyroid cancer [28].

Thus, our research goal was to study primary incidence and structure of thyroid cancer among the population living in Chelyabinsk region over the period 1998-2016 and it seems quite justified.

Materials and methods. We used information on all cases of thyroid cancer contained in the Chelyabinsk Regional Population Oncology Register, the medical database of the Urals Research Center for Radiation Medicine, in the archive of the histological laboratory at the anatomic pathology department of the City Clinical Hospital №1 of Chelyabinsk (in 1985, on the basis of City Clinical Hospital No. 1, a regional center of endocrine surgery was established, where all persons (including children) from Chelyabinsk region who have endocrine pathology are sent to for treatment). As a result of combining information from all available sources and primary analysis, a sampling was made up of 4,467 individuals who lived in Chelyabinsk region from 1998 to 2016, inclusive, with the newly diagnosed thyroid cancer. Repeated references to the same patient were removed from the general list due to duplication of information in different institutions or due to return visit regarding treatment, clarification of the diagnosis, recurrence of the disease or detection of metastases. All relevant consistent information taken from any of the sources mentioned above is taken into account for each patient and thyroid cancer case. These retrospective data were in some way incomplete. For example, the age at which a diagnosis was put was not known for 39 persons $(0.9 \%)$, no sex was indicated for 123 persons $(2.8 \%)$, there was no histological

\footnotetext{
${ }^{1}$ Health effects of the Chernobyl accident and social healthcare programs: a report by "Health" group of experts of the UN Chernobyl forum / English edition edited by: B. Bennet, M. Renazoli, G. Karr; Russian edition edited by M. Balonov. - Geneva, 2006. $-182 \mathrm{p}$.
} 
confirmation of the diagnosis for 302 persons (6.8\%). Data on sex were incomplete due to the following: first, direct indication of sex could be absent; second, there could be surnames that are the same for feminine and masculine gender; third, there could be incomplete information on names and patronymics (only initials are given). When there is no histological examination data, the diagnosis of thyroid cancer was confirmed by cytological examination.

Only in 69 cases out of 4,467 (1.5\%) thyroid cancer was first diagnosed post mortem (neglected cases of thyroid cancer, which led to the death of a patient, or it was accidentally detected during an autopsy in the event of death from other causes). In all these cases the diagnosis was confirmed histologically. For $98.5 \%$ of patients thyroid cancer was diagnosed in their lifetime by an endocrinologist. Thus, calculated standardized parameters of newly diagnosed thyroid cancers can be considered as indicators of primary incidence. The incidence rate was calculated as a number of newly diagnosed thyroid cancers over a period x 100,000/number of person-years over the period under consideration. The data on the population living in Chelyabinsk region over the study period are taken from statistical books of the Chelyabinsk Department of Statics. Alignment of time-series data on thyroid cancer incidence were performed with the standard method of least squares [29]. Statistical processing was carried out with $\chi^{2}$ test and Student's test [30].

\section{Results and discussion.}

Analysis of thyroid cancer incidence and structure dynamics over the period 1998-2016

Distribution of males and females from different age groups with thyroid cancer reveals features of obvious similarities (Figure 1). Predominance of males aged from 20 to 24 y.o. can be an exception $(6.4 \%$ and $2.8 \%$ respectively, $\mathrm{p}<0.001)$. The maximum percentage of males with thyroid cancer $(14.1 \%)$ is detected among people aged 55-59; the highest percentage of females (12.9\%), among people aged 50-54. Males and females with thyroid cancer from the 50-59 age group account for
$26.7 \%$ and $25.3 \%$ respectively, which is consistent with the published data $(15.2 \%-31.1 \%)$ $[1-3,6,18,19]$.

Taking into account a similar type of distribution of males and females by age, as well as taking into account a relatively low number of males with thyroid cancer (629 persons, $14.1 \%$ ) the analysis of incidence was carried out for males and females together. As it can be seen from Figure 2, the incidence in Chelyabinsk region as well as in the Russian Federation as a whole is uneven, while in both cases there is a tendency to an increase in the incidence of thyroid cancer.

We applied the least squares method to calculate parameters of incidence with thyroid cancer taking into account preliminary alignment of time-series data on thyroid cancer incidence over 19 years for Chelyabinsk region

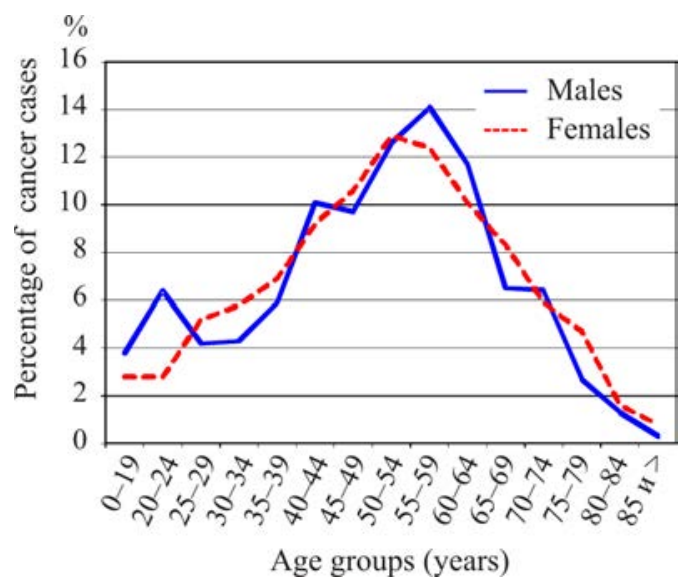

Figure 1. Thyroid cancer distribution (C73 - ICD-10) by age and sex, \%

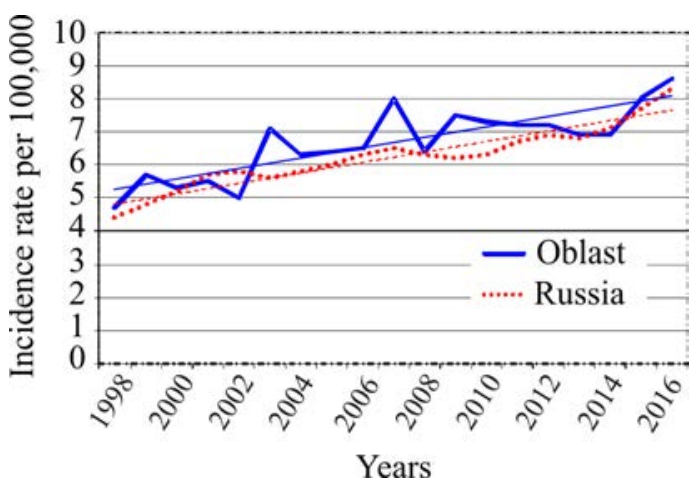

Figure 2. Dynamics of newly diagnosed thyroid cancers over the period 1998-2016 (newly diagnosed cancers per 100,000 persons per a particular year) 
and the RF as a whole; the results turned out to be almost identical [29]. An absolute growth in incidence rates amounted to 0.170 and 0.174 , respectively; an average growth rate was $1.3 \%$ and $1.4 \%$; average value of $1 \%$ of growth -0.026 and 0.028 cases per 100,000 persons.

Thus, the obtained data indicate that this increase in incidence with thyroid cancer in Chelyabinsk region is a reflection of the general Russian trend.

It can be seen that the trend lines of incidence growth go almost parallel (Figure 2). The increase in incidence over the period 1998-2016 in Chelyabinsk region was 3.91; in the Russian Federation, 3.90 cases per 100,000 person-years during the period under review. The rate of changes in incidence, especially in Chelyabinsk region, is uneven. In Chelyabinsk region, the maximum growth was registered in 2007 (by 1.74 cases compared with the previous year), in the Russian Federation the maximum growth was only 0.63 cases and it was achieved in 2015.

Table 1 presents the incidence rates of thyroid cancer for the period 1998-2016 inclusive. Over the whole reviewed period, the primary incidence rate was 6.6 cases per 100,000 person-years and it is consistent with the published epidemiological data for the most countries and the Russian Federation (according to published data, the incidence rate varied within the range 5-10 per 100,000 persons) [1-6, 10-19]. A steady growth of thyroid cancer incidence is registered in Chelyabinsk region as well as in most regions in the RF [31]. As it can be seen in Table 1, there is a steady increase in the dynamics of incidence rates per 100,000 person-years, starting from 5.2 in 1998-2002 to 7.6 in 2013-2016, while an increase in the second five-year period is statistically significant $(\mathrm{p}<0.01)$.

The incidence rate among persons aged 0-19 decreased from 0.9 to 0.3 per 100,000 person-years (Table 2). There were no significant differences in incidence rate between the calendar periods. The average value was 0.6 cases per 100,000 person-years, which corresponds to the published data $[32,33]$.
Table 1

Dynamics of thyroid cancer incidence

\begin{tabular}{|c|c|c|c|}
\hline $\begin{array}{c}\text { Period, } \\
\text { years }\end{array}$ & $\begin{array}{c}\text { Amount of } \\
\text { person-years } \\
\text { for the period }\end{array}$ & $\begin{array}{c}\text { Number of } \\
\text { cases over } \\
\text { the period }\end{array}$ & $\begin{array}{c}\text { Incidence rate } \\
\text { per 100,000 } \\
\text { person-years }\end{array}$ \\
\hline $1998-2002$ & $18,267.677$ & 956 & 5.2 \\
\hline $2003-2007$ & $17,722.374$ & 1,213 & $6.8^{*}$ \\
\hline $2008-2012$ & $17,411.500$ & 1,239 & 7.1 \\
\hline $2013-2016$ & $13,973.315$ & 1,059 & 7.6 \\
\hline Total & $67,374.866$ & 4,467 & 6.6 \\
\hline
\end{tabular}

Note: $*-p<0.001$ when compared with the previous period.

Table 2

Dynamics of thyroid cancer incidence among people aged 0-19

\begin{tabular}{|c|c|c|c|}
\hline $\begin{array}{c}\text { Period, } \\
\text { years }\end{array}$ & $\begin{array}{c}\text { Amount of } \\
\text { person-years } \\
\text { for the period }\end{array}$ & $\begin{array}{c}\text { Number } \\
\text { of cancer } \\
\text { cases }\end{array}$ & $\begin{array}{c}\text { Incidence rate } \\
\text { per 100,000 } \\
\text { person-years }\end{array}$ \\
\hline $1998-2002$ & $4,874.823$ & 43 & 0.9 \\
\hline $2003-2007$ & $4,277.526$ & 25 & 0.6 \\
\hline $2008-2012$ & $3,767.369$ & 20 & 0.5 \\
\hline $2013-2016$ & $3,051.365$ & 10 & 0.3 \\
\hline Total & $15,971.083$ & 98 & 0.6 \\
\hline
\end{tabular}

The maximum incidence rate among people aged 20-59 (Table 3) was detected in the period 2003-2007 and amounted to 8.2 cases per 100,000 person-years, the minimum was registered for the initial period -6.5 cases per 100,000 person-years, the differences are statistically significant when the given periods are compared, $\mathrm{p}<0.001$.

Table 3

Dynamics of thyroid cancer incidence among people aged 20-59

\begin{tabular}{|c|c|c|c|}
\hline $\begin{array}{c}\text { Period, } \\
\text { years }\end{array}$ & $\begin{array}{c}\text { Amount } \\
\text { of person- } \\
\text { years }\end{array}$ & $\begin{array}{c}\text { Number } \\
\text { of cancer } \\
\text { cases }\end{array}$ & $\begin{array}{c}\text { Incidence rate } \\
\text { per } 100,000 \\
\text { person-years }\end{array}$ \\
\hline $1998-2002$ & $10,007.895$ & 652 & 6.5 \\
\hline $2003-2007$ & $10,325.207$ & 844 & $8.2^{*}$ \\
\hline $2008-2012$ & $10,475.736$ & 797 & 7.6 \\
\hline $2013-2016$ & $8,116.241$ & 654 & 8.1 \\
\hline Total & $38,925.079$ & 2947 & 7.6 \\
\hline
\end{tabular}

Note: $*-p<0.001$ when compared with the previous group. 
Table 4

Dynamics of thyroid cancer incidence among people aged 60 and older

\begin{tabular}{|c|c|c|c|}
\hline $\begin{array}{c}\text { Period, } \\
\text { Years }\end{array}$ & $\begin{array}{c}\text { Amount of } \\
\text { person-years } \\
\text { for the period }\end{array}$ & $\begin{array}{c}\text { Number } \\
\text { of cancer } \\
\text { cases }\end{array}$ & $\begin{array}{c}\text { Incidence rate } \\
\text { per 100,000 } \\
\text { person-years }\end{array}$ \\
\hline $1998-2002$ & 3384,959 & 261 & $7.7^{*}$ \\
\hline $2003-2007$ & 3119,641 & 344 & 11.0 \\
\hline $2008-2012$ & 3168,395 & 422 & $13.3^{* *}$ \\
\hline $2013-2016$ & 2805,709 & 395 & 14.1 \\
\hline $\begin{array}{c}\text { Whole } \\
\text { period }\end{array}$ & 12478,704 & 1422 & 11.4 \\
\hline
\end{tabular}

Note:* $-\mathrm{p}<0.001$ when compared to other groups; $* *-p<0.025$ when compared to the previous group.

Thyroid cancer incidence statistically significantly increases among people aged $\geq 60$ (Table 4) from 7.7 cases per 100,000 personyears during the initial period to 14.1 cases per 100,000 person-years in the final period, $\mathrm{p}<0.001$.

Over the entire examined period from 1998 to 2016 (Table 2-4), the highest primary incidence with thyroid cancer was observed among people older than 60, 11.4 cases per 100,000 person-years; the minimum value was detected among people aged $0-19,0.6$ cases per 100,000 person-years. The intermediate values of thyroid cancer incidence were detected among people aged 20-59 and amounted to 7.6 cases per 100,000 person-years. The differences in incidence rates between the age groups are statistically significant, $\mathrm{p}<0.001$.

For the majority of thyroid cancer types (Table 5) their percentage corresponded to that in the world and in Russia [11, 13, 14, 18].
Papillary and follicular thyroid cancers predominated in Chelyabinsk region $(68.1 \%$ and $22.6 \%$, respectively) and it corresponded to the published data. Percentage of different thyroid cancers was comparable for males and females. However, the percentage of the most frequent cancers (papillary and follicular) tended to be higher in females as compared to males, whereas the percentage of rare types of cancer (medullary, undifferentiated cancers) was higher in males.

The dynamics detected in the structure of the main thyroid cancer types was characterized by a gradual increase in the percentage of the papillary cancer from $62.9 \%$ in $2003-2007$ to $73.0 \%$ in $2010-2016$, with the respective decrease in the percentage of the follicular cancer from $25.5 \%$ to $18.2 \%$ (Table 6). Upward tendency in the percentage of medullary cancer, downward tendency in the percentage of other, relatively rare, types of thyroid cancer was also noted.

The age of the patients with newly diagnosed thyroid cancer varied in the range equal to 9-99 years. Mean age at which the disease became apparent, which was assessed mainly based on the date when histological sampling was performed, was $50.7 \pm 0.07$ years (Table 7). It was slightly higher as compared to the data given in the majority of published papers $[2,11,12,14,16,21,22]$. Mean age at which thyroid cancer was diagnosed was $50.9 \pm 0.09$ for females, whereas it was $49.6 \pm 0.22$ for males. The differences are statistically significant $(\mathrm{p}<0.001)$.

The oldest mean age at which thyroid cancer was diagnosed $(66.9 \pm 0.7$ years) (Table 8$)$ was observed for people with undifferentiated

Table 5

Percentage of different thyroid cancers among the population in Chelyabinsk region for the period of 1998 through 2016 depending on sex

\begin{tabular}{|c|c|c|c|c|c|c|}
\hline \multirow{2}{*}{ Sex } & \multicolumn{5}{|c|}{ Types of thyroid cancer } \\
\cline { 2 - 7 } & Papillary, \% & Follicular, \% & Medullary, \% & Undifferentiated, \% & Lymphoma, \% & Other types, \%* \\
\hline Male & 66.8 & 21.3 & 4.9 & 2.7 & 1.5 & 2.7 \\
\hline Female & 68.5 & 22.6 & 3.6 & 2.2 & 1.8 & 1.3 \\
\hline Total & 68.1 & 22.6 & 3.7 & 2.3 & 1.8 & 1.6 \\
\hline
\end{tabular}

Note: * - other types include solid cancers, squamous cancers, embryonal tumors, and metastases of other tumors into the thyroid gland. 
Table 6

Table 7

Distribution of different thyroid cancers among the population in Chelyabinsk region taken in dynamics

\begin{tabular}{|c|c|c|c|}
\hline \multirow{2}{*}{$\begin{array}{c}\text { Calendar } \\
\text { period, years }\end{array}$} & \multicolumn{3}{|c|}{ Types of thyroid cancer } \\
\cline { 2 - 4 } & Papillary & Follicular & Other \\
\hline $1998-2002$ & $64.2 \%$ & $25.5 \%$ & $10.3 \%$ \\
\hline $2003-2007$ & $62.9 \%$ & $27.8 \%$ & $9.3 \%$ \\
\hline $2008-2012$ & $71.4 \%$ & $19.5 \%$ & $9.1 \%$ \\
\hline $2013-2016$ & $73.0 \%$ & $18.2 \%$ & $8.8 \%$ \\
\hline Total & $68.1 \%$ & $22.6 \%$ & $9.4 \%$ \\
\hline
\end{tabular}

Distribution by sex and mean age at the time of thyroid cancer development among the population in Chelyabinsk region in 1998-2016

\begin{tabular}{|c|c|c|c|}
\hline Sex & $\begin{array}{c}\text { Number } \\
\text { of cases }\end{array}$ & $\begin{array}{c}\text { Percent- } \\
\text { age, } \%\end{array}$ & $\begin{array}{c}\text { Mean age } \\
\text { (years) }\end{array}$ \\
\hline Male & 629 & 14.1 & $49.6 \pm 0.22 *$ \\
\hline Female & 3715 & 83.2 & $50.9 \pm 0.09$ \\
\hline Sex is unknown & 123 & 2.7 & $49.6 \pm 0.94$ \\
\hline Total & 4467 & 100.0 & $50.7 \pm 0.07$ \\
\hline
\end{tabular}

Note: ${ }^{*}-\mathrm{p}<0.001$ when compared to females.

Table 8

Mean age of the patients with different types of thyroid cancer

\begin{tabular}{|l|c|c|c|}
\hline \multirow{2}{*}{ Types of thyroid cancer } & \multicolumn{3}{|c|}{ Mean age } \\
\cline { 2 - 4 } & Male & Female & $\begin{array}{c}\text { Total, including persons } \\
\text { with unascertained sex }\end{array}$ \\
\hline Papillary & $48.6 \pm 0.4$ & $50.7 \pm 0.2^{* * *}$ & $50.4 \pm 0.1^{*}$ \\
\hline Follicular & $48.7 \pm 0.8$ & $49.8 \pm 0.2$ & $49.7 \pm 0.2^{* *}$ \\
\hline Medullary & $49.8 \pm 1.1$ & $54.0 \pm 0.6^{* * *}$ & $53.0 \pm 0.6$ \\
\hline Undifferentiated (anaplastic) & $66.6 \pm 1.1$ & $66.5 \pm 0.96$ & $66.9 \pm 0.7$ \\
\hline Other types & $57.7 \pm 1.1$ & $53.0 \pm 1.0^{* * * *}$ & $54.1 \pm 0.8$ \\
\hline
\end{tabular}

Note: ${ }^{*}-\mathrm{p}<0.002$ when compared with the follicular cancer, $\mathrm{p}<0.001$ when compared with all the other types of cancer;

** $-\mathrm{p}<0.001$ when compared with all the other types of cancer, except the papillary cancer;

$* * *-\mathrm{p}<0.001$ when compared with males;

$* * * *-\mathrm{p}<0.002$ when compared with males.

cancers, the youngest one $(49.7 \pm 1.2$ years $)$, for people with follicular cancers $(p<0.001)$. For the majority of thyroid cancer types the oldest age of the disease manifestation was registered for females as compared to that for males. No differences were revealed in case of undifferentiated cancers. In the group of people with "other cancers" males were even older than females $(57.7 \pm 1.1$ years and $53.0 \pm 1.0$, respectively, $\mathrm{p}<0.002)$.

Among 4,344 patients with thyroid cancer with ascertained sex, the females to males ratio was 5.9:1.0. It is slightly higher than the same ratio given in the majority of published papers dealing with thyroid cancer. According to them the sex ratio among people with thyroid cancer is mainly in the range $3: 1-5: 1$ $[1-6,13,14,34]$.

Sex ratio is notably shifted in favor of females with the most frequent types of thyroid cancer: papillary and follicular, and malignant lymphomas. Sex ratio with respect to medullary cancer for the studied group of people from Chelyabinsk region was 4.3 , which is lower than that for papillary and follicular cancers. At the same time it was noted in a number of published papers that the sex ratio for medullary cancers is $1: 1$ [14].

Conclusion. The increase in the number of newly diagnosed thyroid cancers in Chelyabinsk region over the period from 1998 through 2016 could be determined by a number of reasons. It could be associated with improved quality of diagnostics; first and foremost, with large-scale screening of persons suspected of thyroid gland diseases introduced into routine practice, and targeted histological examination of these people. One of the reasons for the increase in the number of cancers, including thyroid cancers, could also be eco- 
logical factor which takes on greater and greater importance with the economic revival and industrial production growth in the whole Russian Federation, and in Chelyabinsk region in particular. It has been stated that the dynamics of the growth in the incidence rate in Chelyabinsk region is generally consistent with that in Russia as a whole. It implies common reasons for the increase in thyroid cancer incidence.

A significant increase in thyroid cancer incidence in elderly people ( $>60$ years) that was noted in the paper could be due to the increased life expectancy in Chelyabinsk region, higher percentage of elderly people in the population structure, and shift in the critical physiological age of thyroid cancer development to higher values.

A descending trend in thyroid cancer incidence among children and teenagers could not be explained straightforwardly. However, relatively low statistics of thyroid cancers among people aged $0-19$ years attracts certain attention (only 98 cases were registered over the whole examined period in Chelyabinsk region).

Some parameters characterizing the structure of thyroid cancers are in line with the published data for the majority of the world and the Russian Federation. The older mean age of females in comparison to that of males at thyroid cancer manifestation $(50.9 \pm 0.09$ and $49.6 \pm 0.22$, respectively, $p<0.001)$, is probably associated with longer life expectancy for females, or with physiological aging of males as compared to females. The revealed agedependent differences are mainly due to papillary and, to a lesser extent, follicular cancer, i.e. those types of cancer for which main etiological factors are iodine deficit and preexisting thyroid gland diseases which are more frequent in females.

Some increase in the percentage of follicular thyroid cancers is probably associated with regional ecological peculiarities, such as low content of iodine in the atmosphere and soil in the Urals region. The percentage of certain cancer types in males and females turned out to be comparable. It suggests similar pathogenetic mechanisms of thyroid cancer development in representatives of both sexes despite great differences in cancer detectability.

It is difficult to explain a higher rate and older mean age of the medullary thyroid cancer occurrence in females as compared to males. It is known that medullary cancers could be one of the manifestations of familial or sporadic form of hereditary complex disorder MEN-2, caused by mutations of the c-RET protooncogene on chromosome 10q11.2. It means that it could occur in either male or female with equal probability. Thus, it could be assumed that in Chelyabinsk region a greater part of medullary thyroid cancers were initiated by the effect produced by exogenous factors, and the revealed differences between two sexes are associated with higher predisposition of females to these factors.

It could be stated that in 1998-2016 the rate and dynamics of thyroid cancer incidence among the population in Chelyabinsk region were mainly consistent with the nation-wide rate (Figure 2). The revealed low incidence rate in childhood and young age requires further follow up and control of the data completeness.

Radioactive contamination of the territory in certain districts in the region and exposure of the population living there in 1950-1960 did not influence the average regional incidence rate of thyroid cancer in the long-term period. Nevertheless the task to determine a radiationinduced risk of thyroid cancer development in representatives from particular groups of exposed population and their offspring continues to be relevant.

From a practical perspective, the significance of this work is in the fact that the obtained results provide reasonable grounds to refuse from large-scale (within the Chelyabinsk region) activities aimed at targeted health check-ups of the exposed persons and their offspring, paying special attention to areas of their compact settlement.

The information that people of older ages (as compared to 1980-1990s) are prone to additional risk of thyroid cancer development is important for Chelyabinsk region. And it 
should be taken into account by endocrinologists and oncologists who are involved in thyroid cancer detection.

The obtained regularities and tendencies will be taken into account in future risk analysis of thyroid cancer development associated with the study of the radiation effects on residents of
Chelyabinsk region who were grouped into the cohort of exposed population.

Funding. The research was not granted any sponsor support.

Conflict of interests. The authors state there is no any conflict of interests.

\section{References}

1. Ferlay J., Soerjomataram I., Ervik M., Dikshit R., Eser S., Mathers C., Rebelo M., Parkin D.M., Forman D., Bray F. GLOBOCAN 2012: Estimated Cancer Incidence, Mortality and Prevalence Worldwide in 2012 v1.0. World Health Organization, 2012, vol. 1.0, no. 11. Available at: http: //publications.iarc.fr/Databases/Iarc-Cancerbases/GLOBOCAN-2012-Estimated-Cancer-IncidenceMortality-And-Prevalence-Worldwide-In-2012-V1.0-2012 (07.05. 2018).

2. Chissov V.I., Starinskii V.V., Petrova G.V. Zlokachestvennye novoobrazovaniya v Rossii v 2006 godu (zabolevaemost i smertnost) [Malignant neoplasms in Russia in 2006 (incidence and mortality)]. Moscow, FGU MNIOI im P.A. Gertsena Rosmedtehnologi Publ., 2008, 248 p. (in Russian).

3. Kaprin A.D., Starinskii V.V., Petrova G.V. Zlokachestvennye novoobrazovaniya v Rossii v 2015 godu (zabolevaemost i smertnost) [Malignant neoplasms in Russia in 2015 (incidence and mortality)]. Moscow, MNIOI im. P.A. Gertsena - filial FGBU NMIRC Minzdrava Rossii Publ., 2017, 250 p. (in Russian).

4. Jemal A., Vineis P., Bray F., Torre L., Forman D. Atlas sovremennoj onkologii [Cancer Atlas]. Atlanta: Amerikanskoe onkologicheskoe obshchestvo, 2014. Available at: http: //canceratlas.cancer.org/assets/uploads/2015/05/Cancer-Atlas-Russian-Compressed.pdf (07.05. 2018) (in Russian).

5. Cancer Incidence in Five Continents Volume X. Edited by D. Forman, F. Bray, D.H. Brewster, C. Gombe Mbalawa, B. Kohler, M. Pineros, E. Steliarova-Foucher, R. Swaminathan, J. Ferlay. IARC Publ., 2014. Available at: http: // publications.iarc.fr/Book-And-Report-Series/Iarc-ScientificPublications/Cancer-Incidence-In-Five-Continents-Volume-X-2014 (07.05. 2018).

6. World Cancer Report 2014. Edited by B.W. Stewart, P.W. Christopher. IARC Publ., 2014. Available at: http://publications.iarc.fr/Non-Series-Publications/World-Cancer-Reports/World-CancerReport-2014 (07.05. 2018).

7. Shalaginov S.A., Startsev N.V., Akleev A.V. Air pollution control regulations and methodology in Russia and the USA for chemical accidents. Meditsina ekstremalnykh situatsii, 2014, no. 4, pp. 18-26 (in Russian).

8. Shalaginov S.A., Startsev N.V., Akleyev A.V. Settling of population exposed to radiation on the Techa River, over the observation period from 1950 to 2010. Mediko-biologicheskiye $i$ sotsialnopsihologicheskiye problemy bezopasnosti v chrezvychaynykh situatsiyakh, 2015, no. 2, pp. 108-114 (in Russian).

9. Shalaginov S.A., Krestinina L.Yu., Startsev N.V., Akleyev A.V. Peculiarities of the resettlement of the first generation offspring of the exposed Techa River population. Radiatsionnaya gigiena, 2017, vol. 10, no. 2, pp. 6-15 (in Russian).

10. Bershteyn L.M. Rak shchitovidnoi zhelezy: epidemiologiya, endokrinologiya, fakty i mekhanismy kantserogeneza [Thyroid cancer: epidemiology, endocrinology, facts and mechanisms of carcinogenesis]. Prakticheskaya onkologiya, 2007, vol. 8, no. 1, pp. 1-8 (in Russian).

11. Braverman L.I. Bolezni shchitovidnoi zhelezy [Thyroid gland diseases]. Moscow, Meditsina Publ., 2000, 417 p. (in Russian).

12. Paches A.I., Propp R.M. Rak shchitovidnoi zhelezy [Cancer of thyroid gland]. Moscow, Meditsina Publ., 1995, 372 p. (in Russian).

13. Davydov M.I., Aksel E.M. Statistika zlokachestvennykh novoobrazovanii v Rossii i stranakh SNG v 2008 godu [Statistics on malignant neoplasms in Russia and CIS countries in 2008]. Vestnik RONTs im. N.N. Blokhina RAMN, 2010, vol. 21, no. 2, p. 160 (prilozhenie 1) (in Russian). 
14. Furlanetto T.W., Peccin S., Schneider M.A., dos Zimmer A.S. [et al.]. Prevalence of thyroid nodules in 40 years old or old women. Rev. Assoc. Med. Bras., 2000, vol. 46, pp. 331-334.

15. Hundahl S.A., Fleming J.D., Fremgen A.M., Menck H.R. A national cancer data base report on 53856 cases of thyroid-carcinoma treated in the US, 1985-1995. Ibid., 1998, vol. 83, pp. 2638-2648.

16. Kang H.W., No J.H., Chung J.H., Min Y.K. [et al.] Prevalence, clinical and ultrasonographic characteristics of thyroid incidentalomas. Thyroid, 2004, vol. 14, P. 29-33.

17. Parkin D.M., Muir C.S., Whelan S.L., Gao Y.T. [et al.]. Cancer incidence in five continents. IARC Publ., 1992, vol. VI, no. 120, 1033 p.

18. Franceschi S., Boyle P., Maison-Neuve P., La Vecchia C. [et al.]. The epidemiology of thyroid carcinoma. Critical Reviews in Oncogenesis, 1993, vol. 4, no. 1, pp. $25-52$.

19. Dedov I.I., Melnichenko G.A., Peyerkova V.A. [et al]. Results of epidemiological surveys for iodine-deficiency diseases within the framework of the Thyromobile project]. Problemy endokrinologii, 2005, no. 5, pp. 32-36 (in Russian).

20. Shtandel S.A., Barilak I.R., Haziev V.V., Gopkalova I.V. [et al.]. Zabolevaniya shchitovidnoi zhelezy i faktory, vliyayuschie na ikh rasprostranyonnost v populatsii [Thyroid gland diseases and factor influencing their prevalence among population]. Ekologicheskaya genetika, 2010, vol. 8, no 1, pp. 42-49 (in Russian).

21. Lundgren C., Hall P., Ekbom A., Frisell J. [et al.]. Incidence and survival of Swedish patients with differentiated thyroid cancer. Int. J. Cancer., 2003, vol. 106, no. 4, pp. 569-573.

22. Romanchishev A.F., Bagaturia G.O., Gostimskiy A.V., Bogatikov A.A. Epidemioligy and specificity of the clinical course of thyroid carcinoma before and after the Chernobyl accident. Vestnik hirurgii im. I.I. Grekova, 2010, vol. 169, no. 1, pp. 68-72 (in Russian).

23. Ivanov V.K., Tsyb A.F., Maksyutov M.A., Tumanov K.A. [et al.]. Problem of thyroid cancer incidence in Russia after the Chernobyl accident: assessment of radiation risks, 1991-2008 follow-up period. Radiatsiya i risk, 2010, vol. 19, no. 3, pp. 33-58 (in Russian).

24. Gerasimov G.A., Figge Dj. Chernobyl: 20 let spustya. Rol defitsita yoda v razvitii zabolevanii shchitovidnoi zhelezy posle avarii na Chernobylskoi AES [Chernobyl: 20 years later. The role of iodine deficiency in the development of thyroid cancer after the Chernobyl accident]. Moscow, 2006, 40 p. (in Russian).

25. Abrosimov A.Yu., Lushnikov E.F., Frank G.A. Radiogenic (Chernobyl) thyroid cancer. Arkhiv patologii, 2001, vol. 63, no. 4, p. 3-9 (in Russian).

26. Nikiforov Y.E., Erickson L.A., Nikiforova M.N., Caudill C.M., Lloyd R.V. Solid variant of papillary thyroid carcinoma: incidence, clinical-pathologic characteristics, molecular analysis, and biologic behavior. Am. J. Surg. Pathol., 2001, vol. 25, no. 12, pp. 1478-1484.

27. Glantz S. Mediko-biologicheskaya statistika [Primer of biostatistics]. Moscow, Praktika Publ., 1998, 459 p. (in Russian).

28. Privalov V.A., Yaitsev S.V. Vliyanie tekhnogennykh faktorov na zabolevaemost rakom shchitovidnoi zhelezy [The influence of technogenic factors on the incidence on thyroid cancer incidence]. Sovremennye aspekty endokrinnoj hirurgii: materialy HI (HIII) Rossijskogo simpoziuma po hirurgicheskoj endokrinologii s mezhdunarodnym uchastiem. St. Petersburg, 2003, vol. 1, pp. 122-129 (in Russian).

29. Ilyin A.A., Rumyantsev P.O., Medvedev V.S. [et al.]. Rak shchitovidnoi zhelezy u detei i podrostkov [Cancer of thyroid gland in children and adolescents]. Materialy IV Vserossiiskogo kongressa. Moscow, 2007, pp. 62-63 (in Russian).

30. Shahtarin V.V., Tsyb A.F., Stepanenko V.F., Marchenko L.F. Correlation between endemic iodine deficiency and radiation-induced thyroid cancer in children and adolescents. Voprosy onkologii, 2002, vol. 48, no. 3, pp. 311-317 (in Russian).

31. Pelizzo M.R., Toniato A., Grigoletto R., Bernardi C., Pagetta C. Papillary carcinoma of the thyroid. A uni- and multivariate analysis of the factors affecting the prognosis inclusive of surgical treatment. Minerva Chir., 1998, vol. 53, no. 6, pp. 471-482.

32. Vini L., Hyer S.L., Marshall J., A'Hern R., Harmer C. Long-term results in elderly patients with differentiated thyroid carcinoma. Cancer, 2003, vol. 97, no. 11, pp. 2736-2742. 
33. Pinskii S.B., Dvornichenko V.V., Kalinin A.P., Repeta O.R. Medullyarnyi rak shchitovidnoi zhelezy [Medullary thyroid cancer]. Sibirskii meditsinskii zhurnal (Irkutsk), no. 1, vol. 76, 2008, pp. 11-16 (in Russian).

34. Donis-Keller H., Dou S., Chi D., Carlson K.M., Toshima K. [et al.] Mutations in the RET proto-oncogene are associated with MEN 2A and FMTC. Hum. Mol. Genet., 1993, vol. 7, no. 2, pp. 851-856.

Shalaginov S.A., Krestinina L.Yu., Domozhirova A.S., Sergiyko S.B. Clinical and epidemiological characteristics of malignant neoplasms in the thyroid gland in Chelyabinsk region population over 1998-2016. Health Risk Analysis, 2019, no. 2, pp. 64-73. DOI: 10.21668/health.risk/2019.2.07.eng

Received: 07.09.2018

Accepted: 15.03.2019

Published: 30.06.2019 